\title{
Effect of Iron Toxicity on Rice Growth in Sulfato-ferruginous Lowland of South Senegal
}

\author{
Sire Diedhiou ${ }^{1,2, ~ *, ~ A r f a n g ~ O u s m a n e ~ K e m o ~ G o u d i a b y ~}{ }^{1}$, Yves Paterne Sagna ${ }^{1}$, Yaya Diatta ${ }^{1}$, \\ Mariama Dalanda Diallo ${ }^{3}$, Ibrahima Ndoye ${ }^{4}$ \\ ${ }^{1}$ Department of Agroforestry, Assane Seck University of Ziguinchor, Ziguinchor, Senegal \\ ${ }^{2}$ Crop and Soil Science Department, Oregon State University, Corvallis, USA \\ ${ }^{3}$ Aquaculture and Food Technologies Department, Gaston Berger University, Saint-Louis, Senegal \\ ${ }^{4}$ Microbiology Laboratory, French Research Institute for Development, Dakar, Senegal
}

Email address:

sdiedhiou@univ-zig.sn (S. Diedhiou), a.goudiaby3461@zig.univ.sn (A. O. K. Goudiaby), y.sagna3950@zig.univ.sn (Y. P. Sagna), y.diatta4452@zig.univ.sn (Y. Diatta),mariama.dalanda.diallo@ugb.edu.sn (M. D. Diallo), ibrahima.ndoye@ird.fr (I. Ndoye)

${ }^{*}$ Corresponding author

\section{To cite this article:}

Sire Diedhiou, Arfang Ousmane Kemo Goudiaby, Yves Paterne Sagna, Yaya Diatta, Mariama Dalanda Diallo, Ibrahima Ndoye. Effect of Iron Toxicity on Rice Growth in Sulfato-ferruginous Lowland of South Senegal. American Journal of Agriculture and Forestry. Vol. 8, No. 1, 2020, pp. 9-14. doi: 10.11648/j.ajaf.20200801.12

Received: January 8, 2020; Accepted: January 20, 2020; Published: February 4, 2020

\begin{abstract}
Rice production in southern Senegal is mainly rain-fed and faces numerous constraints, including iron toxicity. The objective of this study was to determine the effect of iron toxicity on rice yield in Southern Senegal. The study was carried out in farmers' fields in the area of Sindone where two sites were selected (Sites A and B). In each site, six farmers' rice fields covering 2000 to $2500 \mathrm{~m}^{2}$ were selected: three fields with apparent iron oxide (rust) located in lowland and three fields without iron oxide located in highland. Within each of these fields, three plots with dimensions of $300 \mathrm{~m}^{2}$ were delimited and used for the experiment for a total of 18 plots (6*3). Soil cores were taken from all plots in the $0-10 \mathrm{~cm}$ horizon at $0,30,60$ and 90 days after rice transplanting (DAT) to measure soil $\mathrm{pH}$. The intensity of iron toxicity was evaluated on rice plants at different dates and rice yield was determined at harvest at 90 DAT. At 0 and 90 DAT, pH was more acidic compared to 30 and 60 DAT for all plots. Besides, in plots affected by iron oxide, $\mathrm{pH}$ at 0 and 90 DAT was statistically more acidic $(\mathrm{p}<0.01)$ than $\mathrm{pH}$ in non-affected plots. In those plots, despite normal growth and tillering, it was only at 90 DAT that brown spots appeared at the tip of the oldest leaves. In plots affected by iron oxide, at 30 DAT, symptoms of iron toxicity appeared and intensified at 60 and 90 DAT; growth and tillering were reduced with many leaves becoming discolored at both sites. Rice yield decreased by at least $43 \%$ in plots affected by iron oxide for sites A and B. Amendments that will reduce soil acidity would be recommended, this will also improve rice nutrients and increase rice yield.
\end{abstract}

Keywords: Paddy Fields, Acidity, Rust, Iron Toxicity, Rice Yield

\section{Introduction}

In Senegal, and more particularly in Casamance, rice (Oryza sativa L. and Oryza glaberrima Stend) is grown mainly in sulfato-ferruginous lowlands derived from fluviomarine sediments. Iron is one of the most abundant microelement in tropical ferritic and ferruginous soils [1]; [2]. Iron in higher elevation are leached toward the lowlands [3]. In highlands and slopes, iron is generally in the ferric form $\left[\mathrm{Fe}^{3+}\right]$. This form is insoluble and therefore unavailable to plants. In the lowlands, soil which is engorged with water is poor in oxygen and tends to be acidic [4]. In those lowlands, ferric iron is then reduced to ferrous iron $\left[\mathrm{Fe}^{2+}\right][5]$. The presence of ferrous iron or iron oxide (rust) is visible through rusty soil and oily stain in water. In the soil, the excess of iron oxide is shown by red-orange spots. The latter is soluble in water and therefore available for plants that need it in very small quantities. This form of iron, easily absorbable, results in toxicity of plants [6]. The flooding of rice fields thus favors the reduction of iron, which becomes toxic to rice [7]. Iron 
toxicity, also known as yellowing or bronzing, can be defined as a nutritional disorder associated with high concentrations of iron in the soil solution [8].

Symptoms of iron toxicity are small reddish to brown spots on the leaves. The bronzing is used as an indicator of iron toxicity [9]. These spots extend, merge and give a reddish color to the leaves $[7,10,11]$. Manifestations of iron toxicity may be associated with deficiency of phosphorus and zinc; and a decreased in soil chemical fertility [12].

Iron toxicity alters root structure, delays phenological development and causes sterility of panicles $[13,14]$. The symptoms are often associated with limited rice growth (height and tillering), and lower yield $[15,16]$. Rice yield can thus fall from $10 \%$ to $100 \%$ depending on the concentration of iron and the tolerance of the cultivar [16, 17]. However, rice with bronzing does not always result in a decrease of yield $[18,19]$. With the rainy season, the flooding of paddy fields causes a rapid and significant increase in ferrous iron, lowering the $\mathrm{pH}$ and causing a release of more iron $[7,20]$. Over time, with waterlogging, the environment become more acidic with the decomposition of organic matter [7]. The effects of iron toxicity is more pronounced at the end of the rainy season. Many strategies to improve rice yield have been adopted including the use of selected tolerant rice varieties [21, 22], associated with better soil management practices [23]. However, the yield remain low and more land are being affected. In South Senegal more paddy fields are being affected by the presence of iron; however, the impact of this iron toxicity on rice production remains unknown. Determining the impact on rice yield in relation to soil acidity would be essential to carry out better management strategies. This study was carried out to determine the effects of toxicity on rice yield in the South of Senegal.

\section{Materials and Methods}

\subsection{Presentation of the Study Area}

The study area was located in southern Senegal in the village of Sindone, located on the left bank of the Casamance River. The climate is characterized by two seasons: a rainy season of 3 months (July-September) and a dry season of 9 months. The average rainfall is around $1300 \mathrm{~mm}$. Annual average temperatures are $32^{\circ} \mathrm{C}$ during the day and $24^{\circ} \mathrm{C}$ at night. The landscape consists of trees and shrubs on a ferrosol type with a clay-silty texture.

\subsection{Experimental Design and Data Collection}

The local rice variety Kebo was used. The rice was first sown in a nursery for 21 days. Then, the rice was transplanted on the lowlands and the highlands in August 2016.

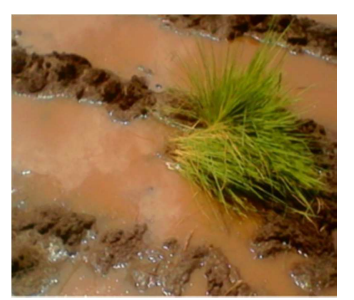

Figure 1. Water in paddy fields affected by iron oxide

The experiment was set up in two sites A and B in farmers' fields located in Sindone. In each site, six (6) rice fields with a size of 2000 to $2500 \mathrm{~m}^{2}$ were chosen for the experiment. A split-plot design was set up with the presence or absence of iron oxide in the two sites. Three of these fields were located in lowland (PfeOx1, PfeOx2, $\mathrm{PfeOx} 3$ ) with the presence of iron oxide (red water with oily or rust spots (Figure 1). The other three fields, located on the highland were considered as plots not affected by iron oxide (P1, P2, and P3). Three plots of $300 \mathrm{~m}^{2}$ were delimited within each field for data sampling for a total of 18 plots $\left(6^{*} 3\right)$. The $\mathrm{pH}$ of the water and the soil was measured using a pH-meter at the day of rice transplanting corresponding to 0 days after transplanting (DAT), at $30 \mathrm{DAT}$, at $60 \mathrm{DAT}$, and 90 DAT. Samples of soil and rice plants were collected from each plot at $0,30,60$ and 90 DAT.

The effect of iron toxicity on the leaves was evaluated by direct observation of the leaves. A grade was assigned according to the standard scale established by the International Rice Research Institute (IRRI) [24] (Table 1). This scale, based on leaf symptoms, varies from 1 to 9 depending on the color.

Table 1. A standard scale of the Iron toxicity Intensity assessment (IRRI) [24].

\begin{tabular}{ll}
\hline Index & Description \\
\hline 0 & Growth and tillering nearly normal \\
1 & $\begin{array}{l}\text { Growth and tillering nearly normal; reddish-brown spots or } \\
\text { orange discoloration on tips of older leaves }\end{array}$ \\
3 & $\begin{array}{l}\text { Growth and tillering nearly normal, older leaves } \\
\text { reddish-brown, purple, or orange-yellow }\end{array}$ \\
7 & Growth and tillering retarded, many leaves discolored \\
9 & Growth and tillering ceases, most leaves discolored or dead \\
\hline
\end{tabular}

At 90 DAT, rice yield was estimated per hectare. The formula of [25] was used.

Yield $=$ NP.ha ${ }^{-1} \times$ NT.P $P^{-1} \times$ Npa.T $T^{-1} \times$ NG.Pa ${ }^{-1} \times$ PG

Where NP.ha ${ }^{-1}=$ number of plants $/$ hectare $=$ NP.m $^{-2} \mathrm{x}$ 10,000

NT.P $\mathrm{P}^{-1}=$ number of tillers / plant;

$\mathrm{Npa} \cdot \mathrm{T}^{-1}=$ number of panicles / tillers;

$\mathrm{NG} \cdot \mathrm{Pa}^{-1}=$ number of grains / panicles;

$P G=$ mass of a grain.

\subsection{Statistical Analyses}

The data was analyzed using the XLSTAT 2014 version 5.03 software. ANOVA was used to analyze the variances of means. The difference in means was subsequently established by Fisher test at the $5 \%$ level. 


\section{Results}

\subsection{Soil pH}

Soil $\mathrm{pH}$ in plots with iron oxide was significantly lower $(\mathrm{P}<$ 0.001 ) compared to plots without iron oxide at 0 and 90 DAT regardless of the site (Figures $2 \& 3$ ). At 0 DAT, plots of the Site A, affected by iron oxide, had an average $\mathrm{pH}$ of 4.29 compared to plots not affected by iron oxide where the $\mathrm{pH}$ was 5.34. In site $\mathrm{B}$, the mean $\mathrm{pH}$ was 4.51 in plots with iron oxide against 5.37 for plots without iron oxide.

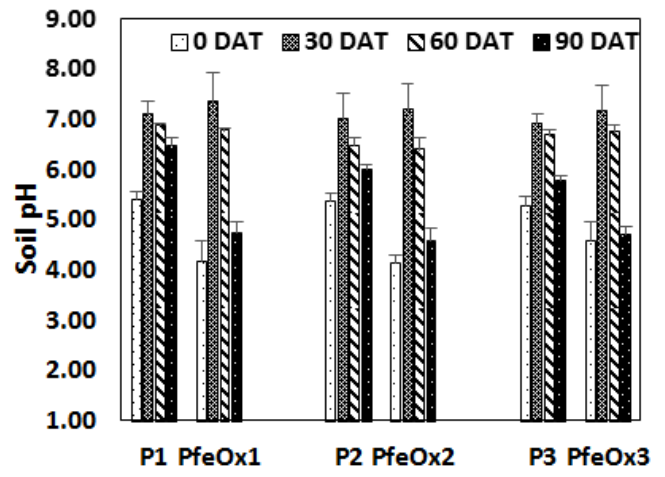

Figure 2. $p H$ data from plots affected and non-affected by iron oxide for site $A$ at $0,30,60$ and 90 days after rice transplanting (DAT).

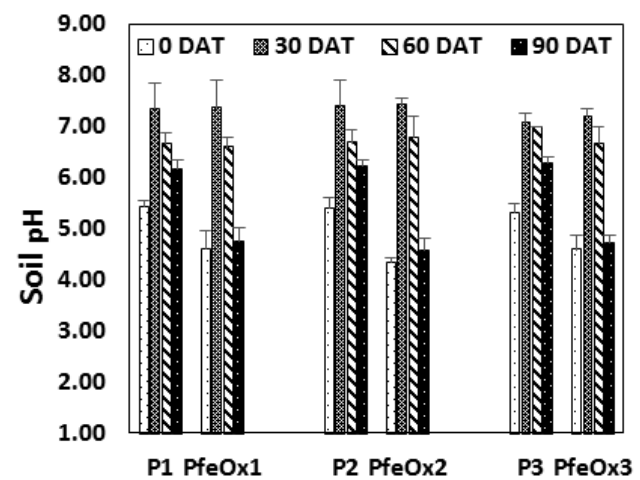

Figure 3. $p H$ data from plots affected and non-affected by iron oxide for site $B$ at 0, 30, 60 and 90 days after rice transplanting (DAT).

There was no significant difference for the $\mathrm{pH}$ at 30 and 60 Figure 3. pH data from plots affected and non-affected by iron oxide for site $\mathrm{B}$ at $0,30,60$ and 90 days after rice transplanting (DAT). DAT between plots with iron oxide and without iron oxide regardless of the site. The $\mathrm{pH}$ at 30 and $60 \mathrm{DAT}$ ranged from 6.63 to 7.32 . These $\mathrm{pH}$ at 30 and 60 DAT were significantly higher than mean $\mathrm{pH}$ at $90 \mathrm{DAT}$, regardless of the presence or absence of iron oxide at both sites A and B (Figures $2 \& 3, \mathrm{P}<0.001$ ). At $90 \mathrm{DAT}$, there was a significant drop in $\mathrm{pH}$ for all iron oxide affected plots: from 6.63 at 60 DAT, the pH dropped significantly to 4.67 for site A ( $\mathrm{P}<$ $0.001)$, and from 6.22 at 60 DAT to 4.68 at 90 DAT for the site $\mathrm{B}(\mathrm{P}<0.001)$.

\subsection{Assessment of the Intensity of Iron Toxicity (IRRI Scale)}

Rice plants in plots not affected by iron oxide grew more and were greener (Figure 4) compared to plants grown on plots affected by iron toxicity, yellowing of leaves (Figure 5).

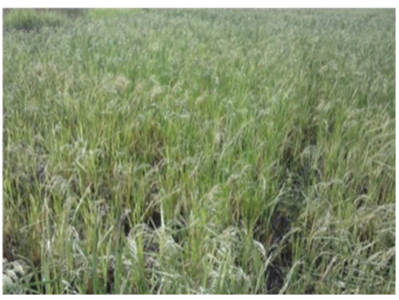

Figure 4. Plants grown on plots not affected by iron toxicity at 60 days after transplanting.

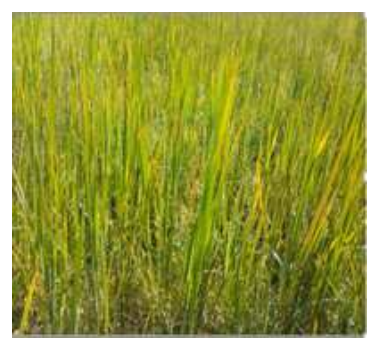

Figure 5. Plants grown on plots affected by iron toxicity at 60 days after transplanting.

In plots not affected by iron oxide, for both sites, rice plants did not have iron toxicity symptoms at 0,30 and 60 DAT (Figure 4, Table 2). It was only at 90 DAT, where, despite normal growth and tillering, brown spots appeared at the tip of the oldest leaves. In sites with the presence of iron oxide, there was no symptom of iron toxicity at 0 DAT. However, at 30 DAT, the older leaves turned orange-yellow. These symptoms intensified at 60 and 90 DAT, growth and tillering were reduced with many leaves becoming discolored for both sites (Figure 5, Table 2).

Table 2. Intensity of Iron Toxicity on rice plants at 0, 30, 60 and 90 days after transplanting (DAT) based on the IRRI Scale on sites $A \& B$.

\begin{tabular}{|c|c|c|c|c|c|c|c|c|}
\hline & \multicolumn{8}{|c|}{ Iron toxicity Intensity (Echelle IRRI) } \\
\hline & \multicolumn{4}{|c|}{ Site A } & \multicolumn{4}{|c|}{ Site B } \\
\hline & 0 & 30 & 60 & 90 & 0 & 30 & 60 & 90 \\
\hline & DAT & DAT & DAT & DAT & DAT & DAT & DAT & DAT \\
\hline \multicolumn{9}{|c|}{ Fields not affected by iron oxide } \\
\hline P1 & 0 & 0 & 0 & 1 & 0 & 0 & 0 & 1 \\
\hline P2 & 0 & 0 & 0 & 1.3 & 0 & 0 & 0 & 0.6 \\
\hline P3 & 0 & 0 & 0 & 1 & 0 & 0 & 0 & 1 \\
\hline \multicolumn{9}{|c|}{ Fields affected by iron oxide } \\
\hline PfeOx1 & 0 & 2.7 & 5.3 & 6.5 & 0 & 2.3 & 4.7 & 6.3 \\
\hline PfeOx2 & 0 & 3.7 & 5.7 & 6.3 & 0 & 3 & 4.3 & 6 \\
\hline PfeOx3 & 0 & 3.3 & 5.3 & 6.7 & 0 & 2.7 & 5 & 6.6 \\
\hline
\end{tabular}

\subsection{Effect of Iron Toxicity on Rice Yield}

Rice yield was statistically higher in plots without iron oxide compared to plots with iron oxide. The yield was 2.21 t.ha $^{-1}$ in plots not affected by iron oxide compared to 1.28 t.ha ${ }^{-1}$ in iron oxide affected plots (Figure 6). The presence of iron oxide led to a $43 \%$ decrease in rice yield in site $\mathrm{A}$ and a $49 \%$ decrease in site $\mathrm{B}$. 


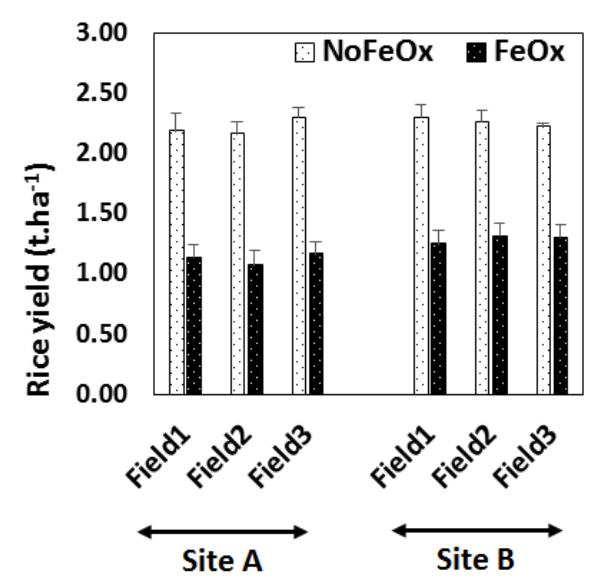

Figure 6. Rice yield on plots not-affected (NofeOx) and affected ( $\mathrm{feOx}$ ) by iron toxicity in both sites $A$ and $B$.

\section{Discussion}

The acidic $\mathrm{pH}$ in all plots with or without iron oxide was characteristic of tropical ferruginous soils with leaching original materials [26]. However, at 0 and 90 DAT, the lower $\mathrm{pH}$ in the lowland paddy fields affected by iron toxicity compared to the $\mathrm{pH}$ in highland rice fields not affected by iron toxicity indicates that there was an acidification that affected the land differently. This is similar to results by $[7,27]$ who found that fields with iron oxide presented much lower $\mathrm{pH}$ compared to field not affected by iron toxicity. Indeed, in lowlands, water stagnates well beyond the rainy season, sometimes during the whole year. This stagnation of water creates anaerobic conditions where organic matter barely decomposes, increasing the acidity of the environment [28]. The difference in acidity at 0 DAT could also be due to a river deposit of sulfated material in the lowlands. Indeed, $[4,7,26]$ found that in the some areas, ferric iron was inherent to the environment, and when there is water, ferric iron is reduced to ferrous iron contributing to acidifying the field. In anaerobic conditions, these sulfato-ferric compounds may be also reduced by sulfate-reducing bacteria which makes the plots more acidic [7]. When the $\mathrm{pH}$ drops to a certain level, below 5, $\mathrm{Fe}^{3+}$ ferric iron is reduced to ferrous iron $\mathrm{Fe}^{2+}$ which will be available to plants. Iron being a micronutrient becomes toxic even at very low doses when the threshold of absorption is exceeded [29]. Acidity could be implicated in the causes of iron toxicity. But we cannot isolate other causes of iron toxicity such as a nutritional imbalance in phosphorus, zinc because we have not measured the content of these elements.

At 30 and 60 DAT, the increase of $\mathrm{pH}$ could be due to a dilution of stagnant rainwater. This is in opposite to studies by [26] who found that the increase in rainfall resulted in submerging the paddy field and contributed to lowering even more the $\mathrm{pH}$. Although the difference is not significant between 30 and 60 DAT, the slight downward trend in $\mathrm{pH}$ at 60 DAT could be due to much lower rainfall quantities and more intense evaporation, creating less diluted conditions. This decrease in rainwater may have also contributed to keeping the $\mathrm{pH}$ at a lower level at 90 DAT that may have intensified the symptoms of iron toxicity and may have affected the development and yield of rice. Similar studies by $[30,31]$ have shown also that iron toxicity affected the growth of rice respectively trough root and shoot development. In conditions of weak iron toxicity, rice can sometimes develop resilience mechanisms but when the toxicity becomes intense, plants will not survive. Mechanisms of rice resilience against iron toxicity have been shown with studies by $[32,33,34]$.

The presence of iron oxide hindered rice yield with a decrease of at least $43 \%$ in plots affected by iron toxicity. Lowland paddy fields affected by iron toxicity have been shown to have lower rice growth and yield [35]. This is in accord with studies by [26] who showed that plots with iron toxicity had lower rice yield compared to plots not affected by toxicity. In lowland, because of the presence of water, the iron is reduced and acidify further the sol. More iron will be available, plant nutrition will be affected and yield will decrease [36, 37]. Similar results were found by [38] who showed that depending on the form of iron and the severity of the toxicity, plant growth will be affected. Furthermore, [39], showed also that rice yield was reduced due to iron toxicity in acidic conditions. When the soil is highly acid, plant absorption of phosphorus and magnesium is reduced, this will affect plant growth [40]. Iron toxicity will cause lower rice yield and depending on the severity of the symptoms, plants will not survive. Our results showed that plots with intense iron toxicity symptoms were associated with the lowest yield. This is in opposite with results by [34, 41] who showed a decrease in rice yield even in plots where plants did not have symptoms of iron toxicity. Yield reduction were observed in plant without significant leaf bronzing [19, 23]. Iron toxicity can sometimes be reduced by applying better fertilization, particularly by adding phosphorus and potassium [42].

\section{Conclusion}

Iron toxicity is a major problem for rice growers in South Senegal. In this study, with the decrease of rainwater, lowland fields became more acidic in plots with the presence of iron oxide compared to plots not-affected by iron oxide. Symptoms of iron toxicity were more intense on plants grown in plots affected by iron oxide compared to plants grown in plots not affected by iron oxide. Rice yield decreased by at least $43 \%$ due to iron toxicity in plots with iron oxide compared to plots without iron oxide. Plots with the lowest rice yield were the one located in lowland areas with more acidic conditions. Given these results, practices to raise $\mathrm{pH}$ in paddy fields must be made. Soil amendments may be used to raise $\mathrm{pH}$; this will also provide plants with nutrients. In addition to adopting better soil management practices, the use of resilient rice varieties may be recommended.

\section{Acknowledgements}

The authors are thankful to Ibrahima Badiane, Ousmane Coly and Boubacar Sonko for their participation in preliminary data collection. 


\section{References}

[1] Chérif, M., Audebert, A., Fofana, M. and M. Zouzou (2009). Evaluation of iron toxicity on lowland irrigated rice in West Africa. Tropicultura, 27: 1970 - 1975.

[2] Adriano A. D (2001). Trace elements in terrestrial environments: biogeochemistry, bioavailability, and risks of metals, Springer, New York. Advances in Agronomy, 99: 183 225.

[3] Diatta S., Audebert A., Sahrawat K. L. and S. Traoré (1998). Lutte Contre la Toxicité Ferreuse dans les Bas-fonds. Acquis de l'ADRAO dans la zone des savanes en Afrique de l'Ouest. Aménagement et mise en valeur des bas-fonds au Mali, Sikasso. CIRAD-CA: 363 - 371.

[4] Sahrawat K. L. (2008). Soil Fertility Advantages of Submerged Rice Cropping Systems. Journal of Sustainable Agriculture, 31 (3): 5 - 23 .

[5] Audebert A. (2006). Iron toxicity in rice: Environmental conditions and symptoms. In: Iron toxicity in rice-based systems in West Africa. Audebert Alain (ed.), Narteh L. T. (ed.), Kiepe Paul (ed.), Millar D. (ed.), Beks B. (ed.). Cotonou: WARDA [Africa Rice Center], 18-33. ISBN 92-9113-300-0

[6] Khouma, M. and M. Toure (1982). Effect of Lime and Phosphorus on the Growth and Yield of Rice in Acid Sulphate Soils of the Senegal. In: On acid sulphate soils, Dost, H. and N. V. Breamen, (Eds.), Bangkok, Thailand, pp: 239 - 250.

[7] Audebert A., Narteh L. T., Kiepe P., Millar D. and B. Beks (2006). Iron toxicity in rice-based systems in West Africa, Africa Rice Center (WARDA), Cotonou, Benin. 175 pp.

[8] Fageria N. K, A. B. Santos and V. A. Cutrim (2008). Nitrogen Uptake and Its Association with Grain Yield in Lowland Rice Genotypes. Journal of Plant Nutrition, 32 (11): 1965 - 1974.

[9] Bode, K., Döring, O., Lüthje, S., Neue, H. U. and M. Böttger (1995). The role of active oxygen in iron tolerance of rice (Oryza sativa L.). Protoplasma, 184: 249 - 255.

[10] Fairhurst, T. H. and C. Witt (2002). Rice: A pratical guide to nutrient management. In A. Audebert, L. T. Narteh, P. Kiepe, D. Millar, \& B. Beks (Eds.), Iron toxicity in rice-based systems in West Africa, Africa Rice Center (WARDA), Cotonou, Benin. $175 \mathrm{pp}$.

[11] Becker, M. and F. Asch (2005). Iron toxicity in rice - condition and management concepts. J. Plant Nutr. Soil Sci., 168: 558 573 .

[12] Kirk, G. J. D. (2003). Rice roots properties for internal aeration and efficient nutrient acquisition in submerged soil. New Phytol., 159: 185 - 194.

[13] Masajo, T. M., Alluri, K., Abifarin, A. O. and D. J. Janakiram, (1986). Breeding for high and stable yields in Africa. In A. S. R. Juo and J. A. Lowe eds., The Wetlands and Rice in sub-Saharan Africa. International Institute of Tropical Agriculture, Ibadan. $107-114$.

[14] Dufey, I., Hakizimana, P., Draye, X., Lutts, S. and P. Bertin (2009). QTL mapping for biomass and physiological parameters linked to resistance mechanisms to ferrous iron toxicity in rice. Euphytica, 167: $143-160$.
[15] Abifarin, A. O. (1989). Progress in breeding rice for tolerance to iron toxicity. In WARDA ed., WARDA Annual report for 1990. West Africa Rice Development Association, Bouaké. 34-39.

[16] Audebert A. and M. Fofana (2009). Rice Yield Gap due to Iron Toxicity in West Africa. Journal of Agronomy and Crop Science, 195 (1): 66 - 76.

[17] Abifarin, A. O. (1988). Grain Yield Loss due to Iron Toxicity. WARDA Technical Newsletter, 8 (1): 1 - 2.

[18] Sikirou, M. (2009). Agro-morphological characterization of lowland rice collection for tolerance to iron toxicity. MSc thesis, Uni. Abomey-Calavi, Benin. pp. 68).

[19] Onaga, G., Edema, R. and G. Asea (2012). Tolerance of rice germplasm to iron toxicity stress and the relationship between tolerance, $\mathrm{Fe}^{2+}, \mathrm{P}$ and $\mathrm{K}$ content in the leaves and roots. Archives Agronomy Soil Science, 59: 213 - 229.

[20] Marius C, and M. Cheval (1980). Note sur les sols de la vallée de Guidel. ORSTOM Dakar.

[21] Audebert, A., \& Sahrawat, K. L. (2000). Mechanisms for iron toxicity tolerance in lowland rice. Journal Plant Nutrition Soil Sciences, 23, 1877 - 1885

[22] Asch, F., Mathias, B., \& Kpongor, D. S. (2005). A quick and efficient screen for resistance to iron toxicity in lowland rice. Journal of Plant Nutrition and Soil Science, 168: 764 - 773.

[23] Sahrawat, K. (2004). Iron toxicity in wetland rice and the role of other nutrients. Journal of Plant Nutrition, 27: 1471-1504.

[24] IRRI. (1996). Standard Evaluation System for Rice (SES). INGER Genetic Resources Center. Manila, Philippines, 4th ed.

[25] Lacharme M. (2001). Le plant de riz: données morphologiques et cycle de la plante. Mémento Technique de Riziculture, fascicule 2. Ministère du Développement Rural et de l'Environnement Direction de la Recherche Formation Vulgarisation (France). 48p.

[26] Gbeto-Dansou G. J., Amadji L. G. L. et H. Aholoukpe (2017). Dynamique de Fer ferreux ( $\mathrm{FeO}$ ) du sol de bas-fond en fonction de la répartition de l'eau selon la toposéquence au Sud du Bénin: Phénomène de la toxicité ferreuse et production du riz. Journal of Applied Biosciences, 110: 10730 - 10746.

[27] Aboa, K. and S. Y. Dogbe (2006). Effect of iron toxicity on rice yield in the Amou-Oblo lowland in Togo. In A. Audebert, L. T. Narteh, P. Kiepe, D. Millar, \& B. Beks (Eds.), Iron toxicity in rice-based system in West Africa (pp. 1-5). Cotonou: WARDA.

[28] van Oort, P. A. J. J. (2018). Mapping abiotic stresses for rice in Africa: Drought, cold, iron toxicity, salinity and sodicity. Field Crops Res., 219: 55 - 75 .

[29] Rout, G. R. and S. Sahoo (2015). Role of iron in plant growth and metabolism. Rev. Agric. Sci., 3: 1 - 24.

[30] Li, G., Kronzucker, H. J. and W. Shi (2016). Root developmental adaptation to $\mathrm{Fe}$ toxicity: Mechanisms and management. Plant Signal. Behav., 11, e1117722.

[31] Wu, L. B., Ueda, Y., Lai, S. K. and M. Frei (2017). Shoot tolerance mechanisms to iron toxicity in rice (Oryza sativa L.). Plant Cell Environ., 40: 570 - 584.

[32] Shamshuddin, J., Elisa, A. A., Shazana, M. A. R. S. and I. C. Fauziah (2013). Rice defense mechanisms against the presence of excess amount of $\mathrm{Al}^{3+}$ and $\mathrm{Fe}^{2+}$ in the water. Aust. J. Crop Sci., 7: 314 - 320. 
[33] Nyamangyoku, I. O. and P. Bertin (2013). Mechanisms of resistance to ferrous iron toxicity in cutivated rices: Oryza sativa L., Oryza glaberrima Steud. and interspecific hybrids. Int. J. Agron. Plant Prod., 4: 2570 - 2591.

[34] Sikirou, M., Saito, K., Dramé, K. N., Saidou, A., Dieng, I., Ahanchédé, A. and R. Venuprasad (2016). Soil-based screening for iron toxicity tolerance in rice using pots. Plant Prod. Sci., 19: $489-496$

[35] Zhang, Y., Wu, Y., Xu, G., Song, J., Wu, T., Mei, X. and P. Liu (2017). Effects of iron toxicity on the morphological and biological characteristics of rice root border cells. J. Plant Nutr., 40: 332 - 343

[36] Kim, S. A. and M. Guerinot (2007). Lou Mining iron: Iron uptake and transport in plants (2007). FEBS Lett., 581: 2273 2280 .

[37] Morrissey, J. and M. L. Guerinot (2009). Iron uptake and transport in plants: The good, the bad, and the ionome. Chem. Rev., 109: 4553 - 4567.

[38] Müller, C., Kuki, K. N., Pinheiro, D. T., de Souza, L. R., Silva,
A. I. S., Loureiro, M. E., Oliva, M. A. and AM. Almeida (2015). Differential physiological responses in rice upon exposure to excess distinct iron forms. Plant Soil, 391: 123 138.

[39] Frei, M., Tetteh, R. N., Razafindrazaka, A. L., Fuh, M. A., Wu, L.-B., Becker, M. (2016). Responses of rice to chronic and acute iron toxicity: Genotypic differences and biofortification aspects. Plant Soil, 408: 149 - 161.

[40] Onaga, G., Dramé, K. N. and A. M. Ismail (2016). Understanding the regulation of iron nutrition: can it contribute to improving iron toxicity tolerance in rice? Funct. Plant Biol., 43: $709-726$

[41] Hua, L., Xiaoe, Y. and L. Ancheng (2001). Ameliorating effect of potassium on iron toxicity in hybrid rice. Journal of Plant Nutrition, 24, 1849-1860.

[42] Prade K., Ottow J. C. G, Jacq V. A., Malouf G. and J. Y. Loyer. (1990). Relationships between the properties of flooded rice soils and iron toxicity in Lower Casamance (Senegal). Studies, review and summary of previous work. Cahiers ORSTOM, Serie Pedologie. IRD, Montpellier, France. p 453 - 474. 